\title{
PHOSPHATE SORPTION PARAMETERS IN RELATION TO SOIL PROPERTIES IN SOME MAJORAGRICULTURAL SOILS OF INDIA
}

\author{
I. Rashmi ${ }^{1}$, V. R. R. Parama $^{* 2}$ and A. K. Biswas ${ }^{1}$ \\ ${ }^{1}$ ICAR-Indian Institute of Soil Science, Bhopal (M.P.), India \\ ${ }^{2}$ Department of Soil Science and Agricultural Chemistry, UAS, Bangalore (Karanataka), India
}

\begin{abstract}
Phosphorus sorption characteristics of some Indian representative agricultural soils belonging to four soil orders namely Vertisol, Inceptisol, Alfisol and Ultisol were investigated for adsorption behaviour of $P$ and sorption data were fitted to Langmuir and Freundlich equations. The Langmuir constant i.e. adsorption maxima was highest for Vertisol $\left(716.85 \mu \mathrm{g} \mathrm{g}^{-1}\right)$, followed by Ultisol $\left(633.3 \mu \mathrm{g} \mathrm{g}^{-1}\right)$, Alfisol $\left(501.46 \mu \mathrm{g} \mathrm{g}^{-1}\right)$ and Inceptisol (522.93 $\left.\mathrm{mg} \mathrm{g}^{-1}\right)$ respectively. The Freundlich ' $\mathrm{k}$ ' value for Vertisol, Inceptisol, Alfisol and Ultisol were 159.12, 59.41, 110.57 and $181.36 \mathrm{\mu g} \mathrm{g}^{-1}$ respectively, whereas the ' $\mathrm{n}$ ' values were $2.05,1.92,2.49$ and $3.07 \mathrm{~g} \mathrm{ml}^{-1}$ respectively. The phosphate adsorption isotherm gave good fit adopting Langmuir $\left(r^{2}=0.96\right.$ to 0.99$)$ and Freundlich $\left(r^{2}=0.95\right.$ to $0.99)$ for the four soils. Phosphorus sorption maxima was significantly correlated with clay $\left(r^{2}=0.70\right)$, Al $\left(r^{2}=0.73\right)$ and $\mathrm{Fe}\left(r^{2}=0.81\right)$ forms, MPBC $\left(r^{2}=0.67\right)$ and Freundlich constants $\left(r^{2}=0.82\right)$. Among the various soil properties which correlated with $\mathrm{P}$ sorption maxima of significance was clay content $\left(r^{2}=0.97\right)$ was significantly correlated. The study illustrated that $\mathrm{P}$ sorption isotherm in relation to soil properties can be used as a tool of $\mathrm{P}$ management in sustainable crop production.
\end{abstract}

Keywords: Phosphorus, sorption maxima, vertisol, inceptisol, alfisol, ultisol, standard $\mathrm{P}$ requirement

\section{INTRODUCTION}

Phosphorus (P) is a critical element both in natural and agricultural ecosystem given its complex transformation in soil thus making its availability to plant difficult especially in tropics. Phosphorus sorption governs the supply of labile inorganic $\mathrm{P}$ (fertilizer P) and the isotherm helps in predicting the efficiency of crops to utilize that labile P. Phosphorus sorption model integrates the quantity and the intensity factors where the former describes the capacity of soil to supply the $\mathrm{P}$ to soil

\footnotetext{
*Corresponding author email: rashmimenon109@gmail.com
}

Received: 17.11.2015 
solution once replenished by plant roots or micro organism, lost from soil, and the later indicates the soil solution P concentration or labile P. It is a well known fact that phosphate adsorption depends upon many soil properties like clay content, $\mathrm{CaCO}_{3}$, organic matter, $\mathrm{Al}$ and Fe content, $\mathrm{CEC}$ as well as $\mathrm{P}$ sources applied to soil (Saha et al., 1999). Phosphorus deficiency gets accentuated with improper $P$ management and crops differ in phosphorus uptake in different soils. Therefore, an attempt was made to investigate $\mathrm{P}$ sorption characteristics and the relationship with properties of major soils of India.

In order to understand the complex behaviour of $\mathrm{P}$ in soil, several workers have emphasized the importance of $\mathrm{P}$ fertilizer management based upon chemical extraction methods (soil-test methods) and phosphate adsorption isotherms (Hue et al., 2000). But, P sorption method has an edge over chemical extraction methods as it also defines the efficiency of the crops to utilise the $\mathrm{P}$ available from soil. Sorption curves also integrate quantity and intensity parameters to characterise the capacity of soil to supply $\mathrm{P}$ to soil solution and predicting fertiliser requirement. Adsorption equations of Langmuir and Freundlich have been used by many workers worldwide to measure relative phosphate sorption capacity of different soils and the affinity of adsorbate to adsorbent (lower is the value higher is the affinity), to understand the sorption phenomenon. The magnitude and rate of phosphate sorption mainly depend upon soil properties like clay content, $\mathrm{CaCO}_{3}$, organic matter, $\mathrm{Al}$ and $\mathrm{Fe}$ content, CEC as well as P sources applied to soil (Majumdar et al., 2005; Ghosh et al., 1999). In acid soils, $\mathrm{Al}$ and $\mathrm{Fe}$ adsorb $\mathrm{P}$ forming various complexes and in neutral soils $\mathrm{P}$ retention on $\mathrm{Ca}$ is dominated by precipitation reactions. The $\mathrm{P}$ sorption isotherm can be used for determination of SPR for most agricultural crops at equilibrium concentration of $0.2 \mathrm{mg} \mathrm{P} \mathrm{L}^{-1}$ soil solution, above this threshold level further there will be no response to $\mathrm{P}$. The amount of $\mathrm{P}$ sorbed at the critical solution $\mathrm{P}$ concentration of 0.2 is important information for comparing the phosphorus adsorption capacity of soils with varying buffering capacities.

The knowledge of $\mathrm{P}$ sorption illustrates supply of phosphates to plants depending upon the concentration of soluble phosphate ions in the soil solution, as well as on the soil's capacity to maintain this concentration. The P deficiency in Indian soil varies from region to region according to soil texture especially clay content, $\mathrm{Al}$ and $\mathrm{Fe}$ oxides, $\mathrm{CaCO}_{3}$, organic $\mathrm{C}, \mathrm{pH}$ etc. This problem gets accentuated with improper $\mathrm{P}$ management and crops differ in phosphorus uptake in different soil. The P fertility data from soils of intensive cultivated area like Punjab revealed that some pockets in India have relatively higher levels of soil $\mathrm{P}$ where $\mathrm{P}$ fertilization could be reduced without jeopardizing the productivity. This is important since almost $90 \%$ of $\mathrm{P}$ fertilizers are imported either directly as finished products or indirectly in the form of raw materials, thus creating a huge fertilizer subsidy. Understanding the relation of the different soil properties, $\mathrm{P}$ sorption parameter will provide a strategy for $\mathrm{P}$ fertilizer management. Therefore a study was conducted with the objectives to determine $\mathrm{P}$ sorption characteristics and their relation with different physico-chemical properties in some major agricultural soil orders of India. 


\section{MATERIAL AND METHODS}

\section{Soil sampling and analysis}

The soil samples were collected from four different orders namely vertisol from Jabalpur, inceptisol from New Delhi, Alfisol from Raipur and Ultisol from Trivandrum. The soil samples collected from all locations were air dried and processed through $2 \mathrm{~mm}$ sieve and used for laboratory analysis and the study was conducted in 2013-14. The physico- chemical properties were determined by routine laboratory procedures. Different forms of $\mathrm{Al}$ and $\mathrm{Fe}$ were extracted as follows (i) Organically bound $\mathrm{Fe}$ and $\mathrm{Al}\left(\mathrm{Fe}_{\mathrm{p}}, \mathrm{Al}_{\mathrm{p}}\right)$ extracted by $0.1 \mathrm{M}$ sodium pyrophosphate $(\mathrm{p})$, (ii) Both amorphous and crystalline forms $\left(\mathrm{Fe}_{\mathrm{d}}, \mathrm{Al}_{\mathrm{d}}\right)$ extracted using dithionatecitrate-bicarbonate (Parafitt, 1988 and Borggaard, 1988), (iii) Organically bound plus inorganic amorphous forms extracted using ammonium oxalate. Amorphous $\mathrm{Fe}$ and $\mathrm{Al}$ were calculated as $\mathrm{Fe}_{\mathrm{o}}-\mathrm{Fe}_{\mathrm{p}}$ and $\mathrm{Al}_{\mathrm{o}}-\mathrm{Al}_{\mathrm{p}}$, and crystalline $\mathrm{Fe}$ and $\mathrm{Al}$ as $\mathrm{Fe}_{\mathrm{d}}-\mathrm{Fe}_{\mathrm{o}}$ and $\mathrm{Al}_{\mathrm{d}}-\mathrm{Al}_{\mathrm{o}}$ respectively.

\section{Phosphorus Sorption}

The $\mathrm{P}$ sorption isotherm was determined by equilibrating (at $30 \pm 1^{\circ} \mathrm{C}$ ) $3 \mathrm{~g}$ soil samples with $30 \mathrm{ml}$ of $0.01 \mathrm{M} \mathrm{CaCl}_{2}$ containing $0,5,10,25,50,75$ and $100 \mathrm{mg} \mathrm{P} \mathrm{L}^{-1}$. Two drops of toluene were added to arrest microbial growth. The suspensions were shaken horizontally for 30 minutes twice, for six days. After six days of equilibration, the suspension was centrifuged at $3500 \mathrm{rpm}$ for $10 \mathrm{~min}$ and the solution $\mathrm{P}$ content in the clear supernatant solution was determined by depletion technique (Olsen and Watanabe, 1957) by ascorbic acid method. The amount of P sorbed was calculated by subtracting the amount of $\mathrm{P}$ in the extract from amount of $\mathrm{P}$ initially added (Fox and Kamprath, 1970). Phosphorus sorbed $\left(\mathrm{mg} \mathrm{kg}^{-1}\right)$ versus $\mathrm{P}$ remaining in solution $\left(\mathrm{mg} \mathrm{L}^{-}\right.$ $\left.{ }^{1}\right)$ was plotted to determine the sorption isotherm. The sorption values of each soil were plotted according to the Langmuir and Freundlich isotherm.

(i) The Langmuir equation described in its linear form is as

\section{$\mathrm{C} / \mathrm{X}=\mathbf{1} / \mathbf{K b}+\mathrm{C} / \mathrm{b}$}

where, $\mathrm{C}$ is equilibrium $\mathrm{P}$ concentration $\left(\mathrm{mg} \mathrm{L}^{-1}\right) ; \mathrm{X}(\mathrm{x} / \mathrm{m})$ is the amount of sorbed $\mathrm{P}$ $\left(\mathrm{mg} \mathrm{kg}^{-1}\right)$;

$\mathrm{b}$ is the constant related to $\mathrm{P}$ sorption maximum $\left(\mathrm{mg} \mathrm{kg}^{-1}\right)$ and $\mathrm{K}$ is the bonding energy $\left(\mathrm{L} \mathrm{mg}^{-1}\right)$, respectively. The Langmuir constants were used to calculate maximum $\mathrm{P}$ buffering capacity (MPBC), which is the product of $\mathrm{P}$ sorption capacity and phosphate affinity constant

(ii) The Freundlich equation takes the form:

$$
\mathbf{X}=\mathrm{KC}^{\mathbf{1 / n}}
$$

By taking the logarithm, Eq. (2) changes into

$\log \mathrm{x} / \mathrm{m}=\log \mathrm{K}+1 / \mathrm{n} \log \mathrm{c}$ 
B. R. R. Parama et al.

where, $\mathrm{X}(\mathrm{x} / \mathrm{m})$ is the phosphorus sorption in $\mathrm{mg} \mathrm{kg}^{-1}$ of soil; $\mathrm{C}$ is the equilibrium concentration in $\mathrm{mg} \mathrm{L}^{-1} ; \mathrm{K}$ and $\mathrm{n}$ are two constants where $\mathrm{n}$ is always greater than unity.

Standard $\mathrm{P}$ requirement (SPR) and external $\mathrm{p}$ requirement (EPR) were calculated by fitting the values of 0.2 and $1 \mathrm{mg} \mathrm{L}^{-1}$ respectively in the Langmuir equations (Dodor and Oya, 2000).

\section{RESULTS AND DISCUSSION}

The physico- chemical properties of the soil orders are shown in table 1.The soil pH of Vertisol, Inceptisol, Alfisol and Ultisol were 7.5, 8.3, 6.3 and 5.5 respectively. The soils were low in organic matter rendering 5.4, 5.4, 4.4 and $4.2 \mathrm{~g}$ $\mathrm{kg}^{-1}$ in Vertisol, Inceptisol, Alfisol and Ultisol respectively. The vertisol were clayey in texture, whereas Inceptisol was sandy loam, Alfisol and Ultisol were sandy clay loam. Olsen P contents of vertisol and inceptisol were 9.48 and $10.74 \mathrm{mg} \mathrm{kg}^{-1}$ and Bray's P contents of Ultisol and Alfisolwere 8.5 and $9.51 \mathrm{mg} \mathrm{kg}^{-1}$ respectively. The cation exchange capacities (CEC) of Vertisol, Inceptisol, Alfisol and Ultisol were $61.66,21.2,11.4$ and $10.27 \mathrm{cmol}(\mathrm{p}+) \mathrm{kg}^{-1}$ of soil respectively.

Table 1. Physico-chemical properties of the experimental soils

\begin{tabular}{|c|c|c|c|c|c|c|c|c|c|c|}
\hline \multirow[t]{2}{*}{ Soil orders } & \multirow[t]{2}{*}{$\begin{array}{c}\mathrm{pH} \\
(1: 2.5)\end{array}$} & \multirow[t]{2}{*}{$\begin{array}{c}\mathrm{EC}\left(\mathrm{dSm}^{-}\right. \\
1)\end{array}$} & \multirow[t]{2}{*}{$\begin{array}{c}\mathrm{OC} \\
\left(\mathrm{g} \mathrm{kg}^{-1}\right)\end{array}$} & \multirow[t]{2}{*}{$\begin{array}{l}\text { Clay } \\
(\%)\end{array}$} & \multirow[t]{2}{*}{$\begin{array}{c}\text { Av. P } \\
\left(\mathrm{mg} \mathrm{kg}^{-1}\right)\end{array}$} & \multirow{2}{*}{$\begin{array}{c}\mathrm{CEC} \\
{\left[\mathrm{cmol}^{(+)}\right.} \\
\left.\mathrm{kg}^{-1}\right]\end{array}$} & \multicolumn{4}{|c|}{$\begin{array}{l}\text { Exchangeable cations } \\
\qquad\left[\mathrm{cmol}(+) \mathrm{kg}^{-1}\right]\end{array}$} \\
\hline & & & & & & & $\mathrm{Ca}$ & $\mathrm{Mg}$ & $\mathrm{K}$ & $\mathrm{Na}$ \\
\hline Vertisol & 7.5 & 0.26 & 5.4 & 55.05 & 9.5 & 61.7 & 15.2 & 6.2 & 3.2 & 7.5 \\
\hline Inceptisol & 8.3 & 0.39 & 5.7 & 19.28 & 9.8 & 21.2 & 5.6 & 3.56 & 0.5 & 8.3 \\
\hline Alfisol & 6.3 & 0.21 & 4.2 & 15 & 8.5 & 11.4 & 3.5 & 2.2 & 0.45 & 3.3 \\
\hline Ultisol & 5.5 & 0.15 & 4.2 & 17.9 & 9.6 & 10.3 & 2.5 & 1.3 & 0.3 & 5.6 \\
\hline
\end{tabular}

The amount of iron and aluminium forms extracted is presented in the table 2.In the present study $\mathrm{Al}_{\mathrm{d}}$ ranged between 2.1 to $16.5 \mathrm{~g} \mathrm{~kg}^{-1}, \mathrm{Al}_{\mathrm{o}} 0.7$ to $2.8 \mathrm{~g} \mathrm{~kg}^{-1}, \mathrm{Al}_{\mathrm{p}}$ 0.3 to $1.3 \mathrm{~g} \mathrm{~kg}^{-1}$. Forms of Iron like $\mathrm{Fe}_{\mathrm{d}}$ ranged between 5.8 to $23.6 \mathrm{~g} \mathrm{~kg}^{-1}, \mathrm{Fe}_{\mathrm{o}} 1.1$ to $4.7 \mathrm{~g} \mathrm{~kg}^{-1}$ and $\mathrm{Fe}_{\mathrm{p}} 0.3$ to $2.0 \mathrm{~g} \mathrm{~kg}^{-1}$ respectively. Aluminium is a predominant cation which is associated with phosphorus regardless of soil reaction $(\mathrm{pH})$ (Pierzynski et al., 1990) and $\mathrm{Fe}$ oxides are reported to be most active $\mathrm{P}$ adsorbent in calcareous soils (Torrent,1994) responsible for P fixation in soil. 
Table 2. Mean values of Aluminium and Iron extractable in pyrophosphate, ammonium oxalate and citrate dithionite $\left(\mathrm{g} \mathrm{kg}^{-1}\right)$ extractants

\begin{tabular}{l|c|c|c|c|c|c|cc|cc}
\hline \multicolumn{1}{c}{ Soils } & $\mathrm{Fe}_{\mathrm{d}}$ & $\mathrm{Fe}_{\mathrm{o}}$ & $\mathrm{Fe}_{\mathrm{p}}$ & $\mathrm{Al}_{\mathrm{d}}$ & $\mathrm{Al}_{\mathrm{o}}$ & $\mathrm{Al}_{\mathrm{p}}$ & Crystalline & \multicolumn{2}{c}{ Amorphous } \\
\hline & & & & & & & $\mathrm{Fe}$ & $\mathrm{Al}$ & $\mathrm{Fe}$ & $\mathrm{Al}$ \\
Vertisol & 13.3 & 2.5 & 0.5 & 4.7 & 1.6 & 0.54 & 3.1 & 10.8 & 1.96 & 1.06 \\
Inceptisol & 5.8 & 1.1 & 0.3 & 2.1 & 0.7 & 0.33 & 1.4 & 4.7 & 0.77 & 0.37 \\
Alfisol & 19.3 & 3.5 & 0.8 & 10.8 & 2.3 & 1.3 & 8.5 & 15.8 & 2.2 & 1 \\
Ultisol & 23.6 & 4.7 & 2 & 16.5 & 2.8 & 1.1 & 13.7 & 18.9 & 3.6 & 1.7 \\
\hline
\end{tabular}

\section{Langmuir and Freundlich adsorption isotherm for $\mathbf{P}$ sorption}

The graphical representation of equilibrium $\mathrm{P}$ concentration versus rate of $\mathrm{P}$ adsorbed on unit mass of soil colloid were used to calculate the maximum sorption capacity of the soils and the affinity of the soil to hold P. In all four soils, the equilibrium $\mathrm{P}$ solution and per unit $\mathrm{P}$ adsorption by soil colloids increased with increasing $\mathrm{P}$ addition (Dhillon et al., 2004). The equilibrium $\mathrm{P}$ concentrations and $\mathrm{P}$ sorbed on all ten soils varied among each other at different levels of $\mathrm{P}$ as shown in figure $1(\mathrm{a} \& \mathrm{~b})$. The phosphorus sorption maximawere determined by fitting the solution $\mathrm{P}$ concentration and adsorbed $\mathrm{P}$ values in langmuir equation. The equilibrium $\mathrm{P}$ concentrations and $\mathrm{P}$ adsorbed on four soils varied among each other at different levels of $\mathrm{P}$ and shown in table 3 . The highest $\mathrm{P}$ sorption maxima followed the order Vertisol $\left(716.85 \mathrm{mg} \mathrm{kg}^{-1}\right)>$ Ultisol $\left(633.33 \mathrm{mg} \mathrm{kg}^{-1}\right)>$ Alfisol $(501.78 \mathrm{mg}$ $\mathrm{kg}^{-1}$ ) >Inceptisol $\left(522.93 \mathrm{mg} \mathrm{kg}^{-1}\right)$. The phosphate adsorption isotherm gave a good fit in case of Langmuir $\left(r^{2}=0.96\right.$ to 0.99$)$ and Freundlich $\left(r^{2}=0.95\right.$ to 0.99$)$ equations as presented in table 3. Similar results were obtained by Quang et al. (1996) and Thakur et al. (2004). The langmuir constants $(b=501.46$ to $716.85 \mathrm{k}=0.09$ to 0.45$)$, Freundlich constants $\left(\mathrm{a}=59.41\right.$ to $181.36 \mu \mathrm{g} \mathrm{g}^{-1}$ and $\mathrm{n}=1.92$ to $\left.3.07 \mathrm{~g} \mathrm{ml}^{-1}\right)$ are illustrated in table 4. High $\mathrm{P}$ sorption maxima in Vertisol was due to high clay content, whereas in Alfisol and Ultisol $\mathrm{Al}$ and Fe sorbed more P. The high P fixing capacity is a major constraint in these soils because $>80 \%$ of $\mathrm{P}$ is unavailable to crop uptake due to sorption, precipitation or both (White, 1981). The binding energy of the soils for $\mathrm{P}$ adsorption decreased with increase in surface coverage and interaction with molecules already adsorbed tends to increase with increasing surface coverage, which is in agreement with (Quang, 1996). The phosphate buffering capacity (PBC or MBC) was found to be highest in Vertisol (279.57), Ultisol (240.65), Alfisol (225.66) and Inceptisol (47.06). The soils with high MBC namely Vertisol, Ultisol and Alfisol have high adsorption capacity and would maintain low P supply in soil solution for a longer period as compared to least buffered soils which can supply ample $\mathrm{P}$ to soil solution. On the other hand, soils with low buffering capacity will have more $\mathrm{P}$ in soil solution and will enhance $\mathrm{P}$ mobility in such soils. 
Table 3. Effect of different levels of $\mathrm{P}$ on Langmuir and Freundlich equation constants

\begin{tabular}{|c|c|c|c|c|c|c|c|c|c|}
\hline \multirow[t]{2}{*}{ Soils } & \multicolumn{3}{|c|}{ Langmuir constants } & \multicolumn{3}{|c|}{ Freundlich constants } & $\begin{array}{c}\mathrm{MBC} \\
\left(\mathrm{ml} \mathrm{g}^{-1}\right)\end{array}$ & \multicolumn{2}{|c|}{$\begin{array}{c}\mathrm{SPR} \\
\left(\mathrm{mg} \mathrm{kg}^{-1}\right)\end{array}$} \\
\hline & $\begin{array}{c}\mathrm{b} \\
\left(\mu \mathrm{g} \mathrm{g}^{-1}\right)\end{array}$ & $\begin{array}{c}\mathrm{k} \\
\left(\mathrm{ml} \mu \mathrm{g}^{-1}\right)\end{array}$ & $\mathrm{r}^{2}$ & $\begin{array}{c}\mathrm{A} \\
\left(\mu \mathrm{g} \mathrm{g}^{-1}\right)\end{array}$ & $\begin{array}{c}\mathrm{n} \\
\left(\mathrm{g} \mathrm{ml}^{-1}\right)\end{array}$ & $r^{2}$ & & 0.2 & 1 \\
\hline Vertisol & 716.85 & 0.39 & 0.99 & 159.12 & 2.05 & 0.95 & 279.57 & 51.87 & 259.34 \\
\hline Inceptisol & 522.93 & 0.09 & 0.97 & 59.41 & 1.92 & 0.99 & 47.06 & 9.25 & 46.23 \\
\hline Alfisol & 501.46 & 0.45 & 0.96 & 110.57 & 2.49 & 0.97 & 225.84 & 41.40 & 155.63 \\
\hline Ultisol & 633.33 & 0.38 & 0.98 & 181.36 & 3.07 & 0.99 & 240.65 & 44.73 & 162.61 \\
\hline
\end{tabular}

The amount of standard phosphorus requirement (SPR) for Vertisol, Inceptisol, Alfisol and Ultisol was $51.87,9.25,41.4$ and $44.73 \mathrm{mg} \mathrm{kg}^{-1}$ respectively in $0.2 \mathrm{mg} \mathrm{P}$ $\mathrm{L}^{-1}$ equilibrium soil solution concentration. The higher values of SRP in case of Vertisol and Ultisol indicate the need for application of $\mathrm{P}$ fertilizers to maintain optimum crop production. However with continuous application of $\mathrm{P}$ fertilisers, enrichment of soil $\mathrm{P}$ levels over time can often lead to $\mathrm{P}$ mobility and contribute to eutrophication from non point sources of $\mathrm{P}$ (agricultural $\mathrm{P}$ ) known as external $\mathrm{P}$ requirement (EPR). External P requirement of Vertisol, Inceptisol, Alfisol and Ultisol was $259.34,46.23,155.63$ and $162.6 \mathrm{mg} \mathrm{kg}^{-1}$ which is equivalent to $581,104,337.6$ and $391 \mathrm{~kg} \mathrm{P} \mathrm{ha}^{-1}$. From environmental point of view P leaching can occur at early stage from coarse textured Inceptisol compared to Vertisol, Alfisol and Ultisol.

\section{Relationship between sorption parameters and soil properties}

The correlation coefficient of $\mathrm{P}$ sorption maxima with soil properties like texture, calcium, aluminum and iron content are presented in table 4. The data illustrated that $\mathrm{P}$ sorption maxima was significantly correlated with clay content $\left(\mathrm{r}^{2}=0.97\right)$. Correlation studies indicated a positive and significant correlation between clay content and calcium ions $\left(\mathrm{r}^{2}=0.99\right)$ and also with CEC $\left(\mathrm{r}^{2}=0.96\right)$. An increasein adsorption maxima values with increasing claycontent of the soil may be attributed to the availability of more surface for adsorption of added and native $\mathrm{P}$ as reported by Bopari and Sharma (2006). In Alfisol and Ultisol the amount and type of clay mineral especially 1:1 type clay minerals may contribute to more $\mathrm{P}$ sorption especially in tropical soil, particularly with low $\mathrm{pH}$ and high activity of $\mathrm{Al}$ and $\mathrm{Fe}$ (Dolui and Dasgupta, 1998). The SPR $\left(0.2 \mathrm{mg} \mathrm{l}^{-1}\right)$ was highly correlated to binding strength coefficient $\left(r^{2}=0.99\right)$ and supporting the fact that energy coefficient of a soil is an important index for planning $\mathrm{P}$ management for weathered soils of tropical regions. The amount of $\mathrm{P}$ adsorption at equilibrium soil solution concentration $1 \mathrm{mg} \mathrm{L}^{-1}$ was 
significantly correlated with binding energy $\left(\mathrm{r}^{2}=0.97\right)$. The soil samples from different locations varied in properties example Vertisol was clayey in texture and high in $\mathrm{CEC}$, acidic Ultisol and Alfisol with high $\mathrm{Al}$ and $\mathrm{Fe}$ content played major role in $\mathrm{P}$ adsorption.

Table 4. Correlation coefficient among sorption parameters and related soil properties of four soils

\begin{tabular}{lcccc}
\hline & $\begin{array}{c}\text { Langmuir } \\
\text { constant }\end{array}$ & \multicolumn{3}{c}{$\begin{array}{c}\text { Freundlich } \\
\text { constant }\end{array}$} \\
\hline Clay & $\mathrm{B}$ & $\mathrm{k}$ & $\mathrm{n}$ & $\mathrm{K}$ \\
\hline Available P status & $0.97^{*}$ & 0.751 & 0.598 & -0.187 \\
Organic carbon & -0.627 & -0.905 & -0.934 & -0.717 \\
$\mathrm{Ph}$ & 0.000 & -0.329 & -0.567 & $-0.934^{*}$ \\
$\mathrm{EC}$ & -0.142 & -0.487 & -0.700 & $-0.968^{*}$ \\
$\mathrm{CEC}$ & -0.267 & -0.395 & -0.583 & -0.669 \\
$\mathrm{Fe}_{\mathrm{ao}}$ & 0.798 & 0.482 & 0.253 & -0.551 \\
$\mathrm{Al}$ & & 0.603 & 0.792 & $0.954^{*}$ \\
Crystalline Fe & 0.275 & 0.574 & 0.769 & $0.92^{*}$ \\
$\mathrm{SPR} \mathrm{Langmuir}_{0.2 \text { mg 1 }}^{-1}$ & 0.272 & 0.440 & 0.654 & $0.96^{*}$ \\
\hline
\end{tabular}

*Significant at $1 \%$ level significance
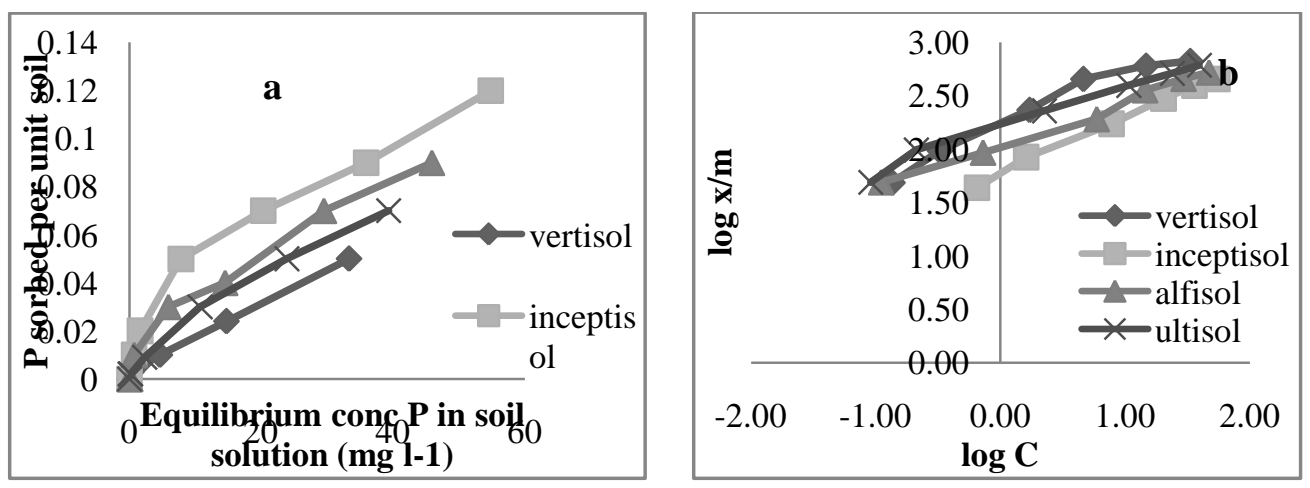

Figure 1. Relationship between $\mathrm{P}$ in equilibrium soil solution and $\mathrm{P}$ sorbed on four soils as shown in (a) Langmuir isotherm and (b) Freundlich isotherm 
B. R. R. Parama et al.

\section{CONCLUSION}

The extent of $\mathrm{P}$ adsorption is considered as an important parameter in understanding $\mathrm{P}$ supplying characteristics of soil and in making fertilizer recommendations. The study on phosphorus adsorption in four major soil orders of India illustrated that the Langmuir and Freundlich adsorption models can be used to describe satisfactorily $\mathrm{P}$ sorption on soil colloids. Among the four soil orders highest P sorption was observed in Vertisol followed by Ultisol, Alfisol and Inceptisol. The correlation study indicated significant correlation $\left(\mathrm{r}^{2}=0.96\right)$ of $\mathrm{P}$ sorption maxima with clay content illustrating that soil texture played a major role in P sorption of these soils. The SPR values indicated high $\mathrm{P}$ requirement in Vertisol and Ultisol as compared to Alfisol and Inceptisol to maintain $0.2 \mathrm{mg} \mathrm{P} \mathrm{L}^{-1}$ in soil solution for optimum crop growth. The high $\mathrm{P}$ adsorption by Vertisol and Ultisol also showed higher phosphate buffering capacity and would maintain low $\mathrm{P}$ in soil solution $\mathrm{P}$ as compared to Alfisol and Inceptisol. Thus the knowledge of $\mathrm{P}$ sorption capacity of soil would be of practical significance and help in $\mathrm{P}$ fertiliser management depending upon soil type.

\section{REFERENCES}

Bopari, K. K. and Sharma. K. N. 2006. Phosphorus adsorption and desorption characteristics of some soils as affected by clay and available phosphorus content. Journal of Indian Society of Soil Science, 54(1): 111-114

Borggaard, O. K. 1988. Phase identification by selective dissolution techniques. In: Stucki JW, Goodman BA, Schwertmann U (eds) Iron in soils and clay minerals. D. Reidel Publishing Company Boston, USApp

Dhillon, N. S., Dhesi, T. S. and Brar, B. S. 2004.Phosphate sorption desorption characteristics of some Ustifluvents of Punjab. Journal of Indian Society of Soil Science, 52:17-22

Dodor, D. E. and Oya, K. 2000.Phosphate sorption characteristics of major soils in Okinawa, Japan.Communication in Soil Science and Plant Analysis, 31: 277-288

Dolui, A. K. and Dasgupta, M. 1998. Phosphate sorption- desorption characteristics of ferruginous soils (Alfisols) of eastern India. Agropedology, 8:76-83

Fox, R. L. and Kamprath, E. J. 1970. Phosphate sorption isotherms for evaluating the phosphate requirements of soils. Soil Science Society of American Proceedings, 34:903906

Ghosh, G. K., Sarkar, A. K. and Sanyal, S. K. 1999. Effect of long-term application of fertilizers on phosphate adsorption and desorption behaviour of some acid soils. Journal of Research Birsa Agriculture University, 11: 123133

Hue, N. V., Ikawa, H. and Huang, X. 2000.Predicting soil phosphorus requirements. In Plant nutrient management in Hawaii soils, ed. J. A. Silva and R. Uchida, 95-99. Honolulu: College of Tropical Agriculture and Human Resources, University of Hawaii 
Majumdar, B., Kumar, K., Venkatesh, M. S. and Ram, P. 2005. Effect of liming on phosphate adsorption and desorption behaviour of acidic Alfisols and Entisol of Meghalaya. Journal of Indian Society of Soil Science, 53: 188-193

Olsen, S. R. and Watanabe, F. S. 1957. A method to determine phosphorus adsorption maxima of soils as measured by the Langmuir isotherm. Soil Science Society of American Proceedings, 21:144 - 149

Parafitt, R. L. and Childs, C. W. 1988. Estimation of forms of $\mathrm{Fe}$ and $\mathrm{Al}$ : a review and analysis of contrasting soils by dissolution of Moessbauer methods. Australian Journal of Soil Research, 26:121-144

Pierzynski, G. M., Logan, T. J., Traina, S. J. and Bigham, J. M. 1990. Phosphorus chemistry and mineralogy in excessively fertilized soils: quantitative analysis of phosphorus rich particles. Soil Science Society of American Proceedings, 54:1576-1583

Quang, S. R., Thai, V. C., Linn, T. T. T. and Dutey, J. E. 1996. Phosphorus sorption in soils of the Mekong Delta (Vietnam) as described by the binary Langmuir equation. European Journal of Soil Science, 47: 113-123

Saha, S., Datta, A. and Sanyal, S. K. 1999. Phosphate sorption-desorption characteristics of some acid soils. Journal of Indian Society of Soil Science, 47:34-39

Thakur, S. K., Tomar, N. K. and Pandeya, S. B. 2004.Sorption of phosphate on pure and cadmium-enriched calcium carbonate and clay. Journal of Indian Society of Soil Science, 52:23-28

Torrent, J. 1994. Iron oxides in Mediterranean soils: Properties and influence on soil behaviour p. 2-14. In Trans International Congress of Soil Science $15^{\text {th }}$ Acapulco, Mexico. 10-16 July 1994. Vol. 8 ISSS, Vienna

White, R. E. 1981.Retention and release of phosphate by soil and soil constituents. In: Tinker $\mathrm{PB}$, editor. Soils and agriculture, critical reports on applied chemistry, Vol. 2. Oxford: Blackwell. p. 71-114 